\title{
Assessing the Influence of Land-Use Changes on Water Quality Using Remote Sensing and GIS: A Study in Cirata Reservoir, Indonesia
} \author{
Santoso ${ }^{1}$ \\ ${ }^{1}$ Department of Biology, Faculty of Mathematic and Natural Sciences, Universitas Padjadjaran, Sumedang 45363, Indonesia \\ ${ }^{2}$ Postgraduate School, Universitas Padjadjaran, Bandung 40132, Indonesia \\ ${ }^{3}$ Center for Environment and Sustainability Science, Universitas Padjadjaran, Bandung 40132, Indonesia \\ ${ }^{4}$ Department of Fisheries, Faculty of Fisheries and Marine Science, Universitas Padjadjaran, Sumedang 45363, Indonesia \\ ${ }^{5}$ Research Unit for Clean Technology, Indonesian Institute of Sciences, Bandung, 40135 Indonesia \\ ${ }^{6}$ School of Earth and Environmental Science, Faculty of Science, The University of Queensland, Brisbane 4072, Australia \\ *Corresponding Author e-mail: sunardi@unpad.ac.id
}

Sunardi Sunardi ${ }^{1,2,3 *}$, Ilyas Nursamsi ${ }^{1,6}$, Moh. Dede $^{3}$, Amalia Paramitha ${ }^{1}$, Mochamad Candra Wirawan Arief $^{3,4}$, Miranti Ariyani ${ }^{5}$, Prihadi

\section{Abstract}

Environmental Changes in a round of reservoirs have dramatic influences on the sedimentation and deterioration of water quality. A significant land-use change in the Cibalagung sub-watershed has an impact on the water quality in the Cirata reservoir. In this study, we used remote sensing and GIS to investigate the influence of land-use changes on water quality in the Cibalagung subwatershed, Cirata reservoir in 2004-2014. We use Knowledge-Based Classification (KBC) and Fuzzy Logic (FL) to determine the land-use classification. The influence of land-use changes on Total Suspended Solids (TSS), as the main parameter of water quality, was determined by path analysis. This study indicated that $92.50 \%$ of land-use changes through increasing mixed plantations, cropland, settlements, and grassland could affect the TSS content in the reservoir. Decreasing vegetated land had a simultaneous effect to reduce the water quality.

\section{Keywords}

Cirata reservoir, GIS, Land-Use Changes, Remote Sensing, TSS.

\section{INTRODUCTION}

A reservoir serves multiple functions, such as hydro-energy, irrigation, flood control, water resource, river ecological indicator, transportation, recreation, agriculture, and aquaculture activities (Simonovic, 1992; Raje and Mujumdar, 2010; Varol, 2020). However, a variety of problems such as sedimentation, flooding, water pollution, water allocation, and debris in reservoir systems (George et al., 2017) can threaten the sustainability of the reservoir functions. Water resource management and development planning, therefore, are required to estimate the sustainability of reservoirs and ensure economic feasibility, environmental standards, and adequate socio-economic opportunities for the local communities (Chen and Tsai, 2017). Sedimentation is one of the complex problems in the context of reservoir management. This problem is associated with water availability as a provisioning system, sustainable development which deals with watershed degradation, floods system, and dam infrastructure (Annandale, 1987; Li et al., 2008). Sedi- mentation has been used as an indicator of water pollution in reservoirs. A few studies on reservoir sedimentation have been carried out in many countries. In China, it is caused by hydrological morphometric and lack of environmental management (Jiang and Fu, 1998; Li et al., 2011). Meanwhile in Europe, especially in France, Spain, and Italy, the controlled sediment flushing triggers reservoir sedimentation which damages the freshwater ecosystem from contaminants (Muñoz et al., 2006; Espa et al., 2016; Lepage et al., 2020). Without proper environmental management, reservoir sedimentation is a common problem for dams in Japan, Taiwan, and the United States (Graf et al., 2010; Chen and Tsai, 2017; Nukazawa et al., 2020).

Sedimentation is strongly influenced by the surrounding environment or landscape conditions. Land-use changes in watershed areas have a significant impact on the reservoir by reducing the water quality and dissolved oxygen; increasing the sedimentation, and disturbing primary productivity by increasing nutrients loading into the stream water flow (Erol and Randhir, 2013). Similarly, the environmental quality around 
the reservoir can also affect the water quality and dynamics of the watershed flow (Ho et al., 2017). Cirata reservoir was built in Citarum River Basin in 1984, serving as a hydropower plant for the Java-Bali region as well as for irrigation and aquaculture (PJB BPWC, 2019). At present, the ecosystem around the Cirata Reservoir is continuously degrading due to complex anthropogenic activities within the reservoir and around the river basin, which in turn leads to water quality deterioration and affects the social and economic resilience of the local communities (Parikesit et al., 2005; Sunardi et al., 2020). Cibalagung is in the most critical condition due to the high pressure of human activities, the river brings many high loads of suspended material $(216.61 \mathrm{~kg} /$ day $)$ into Cirata Reservoir after the Cisokan River (Kartamihardja and Krismono, 2016).

Numerous studies have been conducted to illustrate the land-use and land cover dynamics in the watershed area and its impact on the sedimentation rate in the tropical reservoir using GIS-based analysis (Welde and Gebremariam, 2017; Abdulkareem et al., 2019; Razad et al., 2020). However, knowledge on land-use changes and dynamics as the determining factors of the water quality of tropical reservoirs, particularly at the level of sub-watershed, is still limited. Few studies have been conducted to investigate the impacts of land-use changes in the Upper Citarum and Cimanuk watershed in West Java (Firdaus et al., 2013; Siswanto and Francés, 2019) and Batang Merao watershed in West Sumatra (Ridwansyah et al., 2020), but none were performed on a sub-watershed scale. An accurate analysis of the relevant aspects needs to be carried out to provide an advanced system of preventative and reservoir conservation actions. For such reasons, the objectives of the study were to investigate the land-use changes and to further determine the direct and indirect effect of its changes to TSS level in the Cirata Reservoir. TSS is the main parameter of water quality, it is related to critical land, soil erosion, flood, and river-coastal sedimentation which bring many social-economic problems in the watershed (Dede et al., 2019; Widiawaty et al., 2021).

\section{RESEARCH METHODS}

\subsection{Study Site}

The Cibalagung sub-watershed is located in the southwest part of the Cirata catchment (Figure 1). The sub-watershed connects to the Cirata through the Cibalagung River, which is part of the Cianjur Regency, West Java, Indonesia. The Cibalagung sub-watershed has a total area of around $45 \mathrm{~km}^{2}$ with the range of flow discharge rate of about $0.80-21.14 \mathrm{~m}^{3} / \mathrm{s}$ and TDS concentration of around 75.00-148.33 mg/L (Wahyudiana, 2019) The characteristics of the sediment are clay (3.87-28.33 $\%$ ), fine-coarse sand (70.20-71.50 \%), and gravels (0.17-25.93 \%) (Moelyo and Januar, 2012).

\subsection{Data Analysis}

Land-use changes were analyzed by classifying a series of remote sensing imagery of Landsat-7 ETM+ (2004, 2009, and 2014) using Knowledge-Based Classification (KBC) and Fuzzy Logic (FL) in QGIS 2.4 and GRASS GIS. KBC and
FL techniques for quantification of pixel membership were frequently used in land-use changes studies (Al Fugara et al., 2009; Mousavi et al., 2019). Remote sensing-based analysis was employed to estimate and interpret images from Landsat data visually and digitally to produce a multi-temporal landuse map, including the vegetation cover conditions (Widiawaty, 2019). In addition, remote sensing imageries were widely used in various fields of research, such as urban studies (Zhang et al., 2014; Dede et al., 2021), rural and forest ecosystems (Mancino et al., 2020), dams, and river basins (Hassani et al., 2015; Gounaridis et al., 2014; Zaimes et al., 2019), also coastal and marine ecosystems (El-Askary et al., 2014; Nguyen et al., 2020; Widiawaty and Nandi, 2020). In this study, the image was classified into seven land-use categories according to the Indonesia Ministry of National Land and Land-use and SNI 7645:2010 (Indonesian National Standard) on land-use mapping, which covers dryland forest (DF), mixed plantations (MP), cropland $(\mathrm{CL})$, grasslands (GL), settlements (SM), open field (OF), and water bodies (WB).

The overall accuracy was obtained from the comparison between the total number of pixels that are classified correctly in all land-use classes with the total number of pixels from the sample obtained from observations. The accuracy assessment (error matrix) contains the producer's accuracy, user's accuracy, and overall accuracy, which were estimated using Equations (1-3) below. Further evaluation of classification results was carried out by the Kappa formula (Congalton, 1991; BenDavid, 2008; Ismail et al., 2020), and purposively tested via fieldwork in 50 randomly selected locations for each land-use class for supplementary data.

$$
\begin{aligned}
& \text { Producer's accuracy }=\frac{\mathrm{X}_{\mathrm{kk}}}{\mathrm{X}_{\mathrm{k}+}} \times 100 \% \\
& \text { Ucer's accuracy }=\frac{\mathrm{X}_{\mathrm{kk}}}{\mathrm{X}_{+\mathrm{k}}} \times 100 \%
\end{aligned}
$$

$$
\text { Overall accuracy }=\frac{\Sigma \mathrm{X}_{\mathrm{kk}}}{\mathrm{N}} \times 100 \%
$$

where $\mathrm{X}_{\mathrm{kk}}$ is the number of pixels classified correctly in each category, $\mathrm{X}_{\mathrm{k}+}$ is the number of pixels in each training set of each category, $\mathrm{X}_{+\mathrm{k}}$ is the number of pixels classified in each category, $\Sigma X_{\mathrm{kk}}$ is the number of pixels classified correctly in all categories, and $\mathrm{N}$ is a number of reference pixels.

To find out the importance and significance impact values of land-use changes to the changes in the value of Total Suspended Solids (TSS) concentration in the respective year, we use statistical method through the path analysis with additional trimming (Teas et al., 1979; Cramer et al., 1999) (Figure 2). TSS concentration data from the year 2004 to 2014 was obtained from PT Java Bali Powerplant (PT PJB) report. TSS was measured at the intake point of Cibalagung river to Cirata 

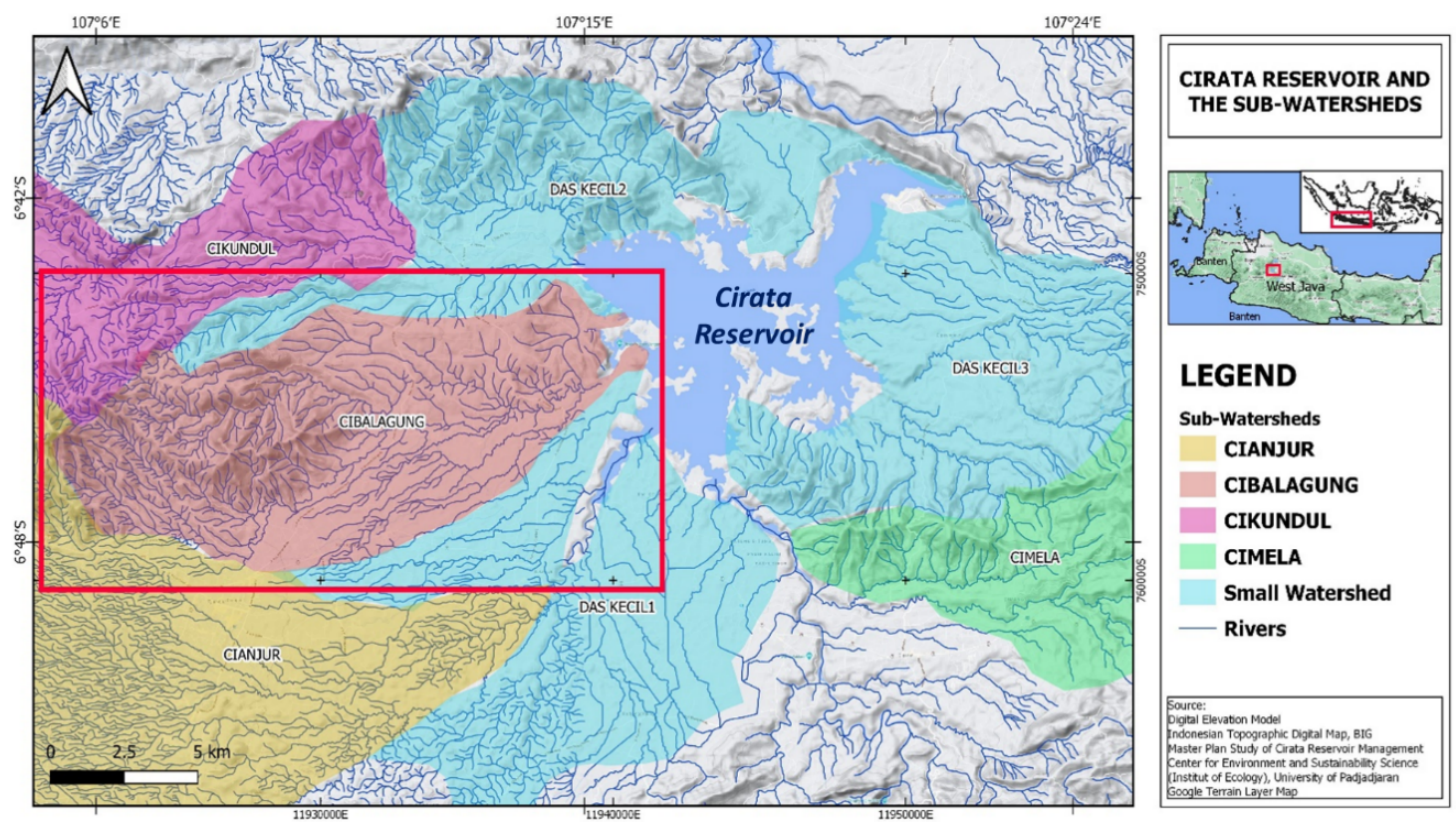

Figure 1. Cibalagung Sub-Watershed is Located in The West of Cirata Reservoir.

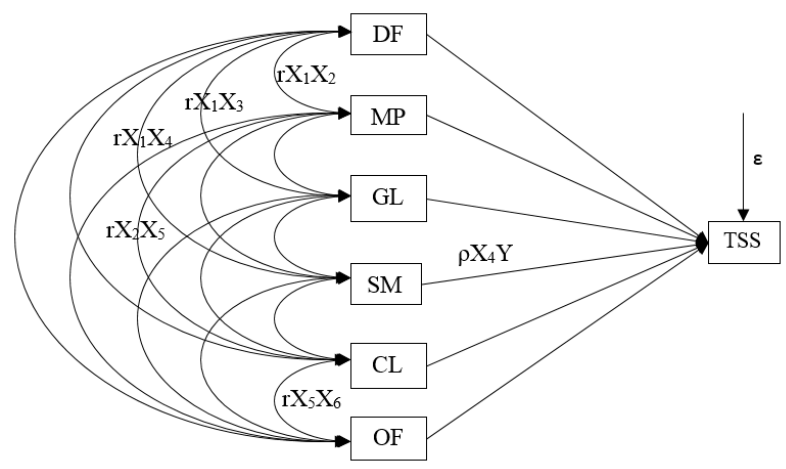

Figure 2. Interaction Between Land-Use and TSS.

Reservoir (estuary). Based on a dynamic model, TSS was increased to $21.62 \%$ from 2004-2014, this level will increase to $82.76 \%$ in 2045 (Widiyati, 2011). All of these land-use classes were analyzed through correlation and linear regression analysis with the coefficient of linear structural equations representing the causal relationship directly or indirectly to the changes in TSS concentration (Chen et al., 2015; Wang et al., 2015). Path analysis was designed to estimate the direct relationships among the stimuli (land-use category changes) and the response (TSS changes), while also estimating the indirect effect of stimulus interactions onto the response (Imen et al., 2015). We arranged conceivable paths that linked each landuse category to the response, as well as among the stimulus to illustrate its direct and indirect impact. The direct impact value of each land cover change towards TSS dynamics was retrieved from the $\beta$ coefficient values. Meanwhile, the indirect impacts of a certain land cover changes correlated to changes in other land cover types were calculated via the following Equation (4).

$$
\operatorname{IE}_{\mathrm{Xi}} \rightarrow \mathrm{Y}\left(\mathrm{ViaX}_{\mathrm{j}}\right)=\left(\left(\rho \mathrm{X}_{\mathrm{i}} \mathrm{Y}\right) \mathrm{x}\left(\mathrm{rX}_{\mathrm{i}} \mathrm{X}_{\mathrm{j}}\right) \mathrm{x}\left(\rho \mathrm{X}_{\mathrm{j}} \mathrm{Y}\right)\right)
$$

where IEX $_{\mathrm{i}}$ is the indirect effect of land-use class ${ }_{\mathrm{i}}$ via landuse class ${ }_{j}$, Y changes in TSS, $\rho \mathrm{X}_{\mathrm{i}}-\mathrm{Y}$ is a direct effect of land-use class ${ }_{i-j}$ to the TSS changes, and $\mathrm{rX}_{\mathrm{i}} \mathrm{X}_{\mathrm{j}}$ is a correlation between land-use classes.

\section{RESULTS AND DISCUSSION}

\subsection{Land-Use Changes}

The land-use classification result was validated using a matrix accuracy test and we obtained a high degree of mapping accuracy (Table 1). The result showed that the overall accuracy of all land-use classes was $91.14 \%$ with a Kappa index value of 0.89 . This kappa index indicates the possibility of avoiding errors in maps production of around $89.50 \%$. This level of accuracy is well above the classification accuracy standard in land-use mapping derived from remote sensing data, which should be as minimum as $80 \%$ (Widiawaty et al., 2020a). In this study, the highest producer's accuracy was obtained for dryland forest $(96.34 \%)$ and the lowest was for water bodies $(83.82 \%)$. Meanwhile, the highest user accuracy was obtained for mixed plantations $(97.75 \%)$, and the lowest was for the open field class $(72.10 \%)$. The highest accuracy obtained ensures that the most appeared land-use class on the map have been well characterized (Giri, 2012), while the accuracy value obtained below the standard limit shows the inaccuracy of landuse classification due to the error in translating the land-use classes with similar spectral signatures.

Furthermore, the reliability of the land-use classification was assessed by comparing the kappa index value and the over- 
Table 1. Confusion Matrix of Accuracy Classification in 2014

\begin{tabular}{cccccccccc}
\hline $\begin{array}{c}\text { Reference } \\
\text { class }\end{array}$ & DF & MP & CL & PR & DF & MP & CL & Row total & Producer's \\
accuracy (\%)
\end{tabular}

all accuracy (Congalton and Green, 2019). Since the kappa index value was lower than the overall accuracy obtained, the land-use classification based on Landsat-7 ETM+ in 2014 imagery had good accuracy and was deemed acceptable for further analysis. Land-use classes during the 2004-2014 period were dominated by dryland forest (Table 2), which covered more than $30 \%$ of the Cibalagung sub-watershed. This study also shows that, while the dryland forest decreased due to the landuse conversion, all the other types of land use found in the Cibalagung sub-watershed increased in size during the period. Overall, for one decade, the dryland forest decreased by about 1077.78 ha (-19.65\%). However, the grassland area increased up to 57.96 ha $(+3.45 \%)$. Along with the grassland, the other types of land use, such as mixed plantations, cropland, and settlements also increased in size by about $3.99 \%, 23.32 \%$, and $49.86 \%$, respectively. An extreme change of dryland forest area to grassland was occurred due to logging activities, which were then followed by the growth of grasses and reeds until they formed grassland.

The majority of land-use changes were occurred by converting the dry forest area into grassland and mixed plantations (Figure 3). This condition was exacerbated by the development of massive settlements and the road network along the northwest, east, and northeast parts where the dry forest was located previously. Furthermore, the existence of cropland which dominated the center area in the southern part of the sub-watershed continued by the mixed plantations expanding from the southern part to the northeast part. Most of them were located along with the river network which probably leads to the increase of sedimentation rate in the river (Siswanto and Francés, 2019).

\subsection{Influence of Land-Use Changes on TSS}

The Path analysis with the Trimming method showed that there were two exogenous variables with $\alpha>0.05$, i.e., the dryland forest and open field (see Table 3) that have no significant effect on the changes in TSS value. Thereby, both of those variables were excluded from the subsequent Path analysis, the remaining mixed plantations (MP), cropland (CL), grassland $(\mathrm{GL})$, and settlements (SM) classes were then included for the second path analysis calculation (see Figure 4). In the Partial correlation analysis (Figure 4), each of the land-use class' interrelation was assessed and shows both positive and negative relations to each other. Mixed plantations (MP) or cropland (CL) with settlement (SM) and cropland (CL) with settlement (SM) had a strong positive relationship to the changes in TSS values, with coefficient values of $0.78,0.71$, and 0.99 , respectively. While, the relation between grassland (GL) with both mixed plantations (MP) and cropland (CL) were negative, with coefficient values of -0.72 and -0.12 , respectively. There was no significant correlation between grassland (GL) with settlements (SM). While the simultaneous correlation coefficient for overall groups was 0.64 showing a fair interaction among land-use classes (Figure 4) (Setiawan et al., 2019). The direct effects of each land-use class were shown via direct arrow path from the land-use class to the TSS showing that the highest direct effect to the TSS was from mixed plantations $(0.45)$ while grassland had the lowest direct effect (0.05).

Analysis of correlation between land-use changes and the TSS dynamic changes at the reservoir was obtained through correlation and linear regression analysis, with the coefficient of linear structural equations, representing the causal relationship directly or indirectly to the changes in TSS concentration (Table 4). TSS concentration or water turbidity level is one of the main parameters for measuring water quality which has an important role in the formation of the physical landscape and ecological regulatory systems (Widiawaty et al., 2020b). The types and spatial patterns of land-use/land cover in the watershed have different effects on the TSS content in the river (Shi et al., 2017). We found that land-use classes that contributed to significant changes in TSS were mixed plantations, cropland, grassland, and settlements, representing a total effect of 92.50 $\%$.

Between 2004 and 2014, the increase of mixed plantations, settlements, and cropland was driven by logging and land clearing activities in the dryland forest which had a fairly strong 
Table 2. Land-Use Area in The Three Periods

\begin{tabular}{ccccccc}
\hline \multirow{2}{*}{ Land-use } & \multicolumn{2}{c}{2004} & \multicolumn{2}{c}{2009} & \multicolumn{2}{c}{2014} \\
& ha & $\%$ & ha & $\%$ & ha & $\%$ \\
\hline Dryland forest (DF) & $5,483.33$ & 41.79 & $3,980.97$ & 30.34 & $4,406.10$ & 33.58 \\
Mixed plantations (MP) & $3,077.73$ & 23.46 & $2,999.43$ & 22.86 & $3,200.76$ & 24.39 \\
Cropland (CL) & $2,238.03$ & 17.06 & $2,408.24$ & 18.36 & $2,759.95$ & 21.05 \\
Grassland (GL) & $1,679.58$ & 12.8 & $2,872.52$ & 21.89 & $1,737.54$ & 13.24 \\
Settlements (SM) & 633.33 & 4.83 & 767.34 & 5.85 & 949.14 & 7.23 \\
Open field (OF) & 0 & 0 & 92.5 & 0.7 & 67.4 & 0.51 \\
\hline
\end{tabular}
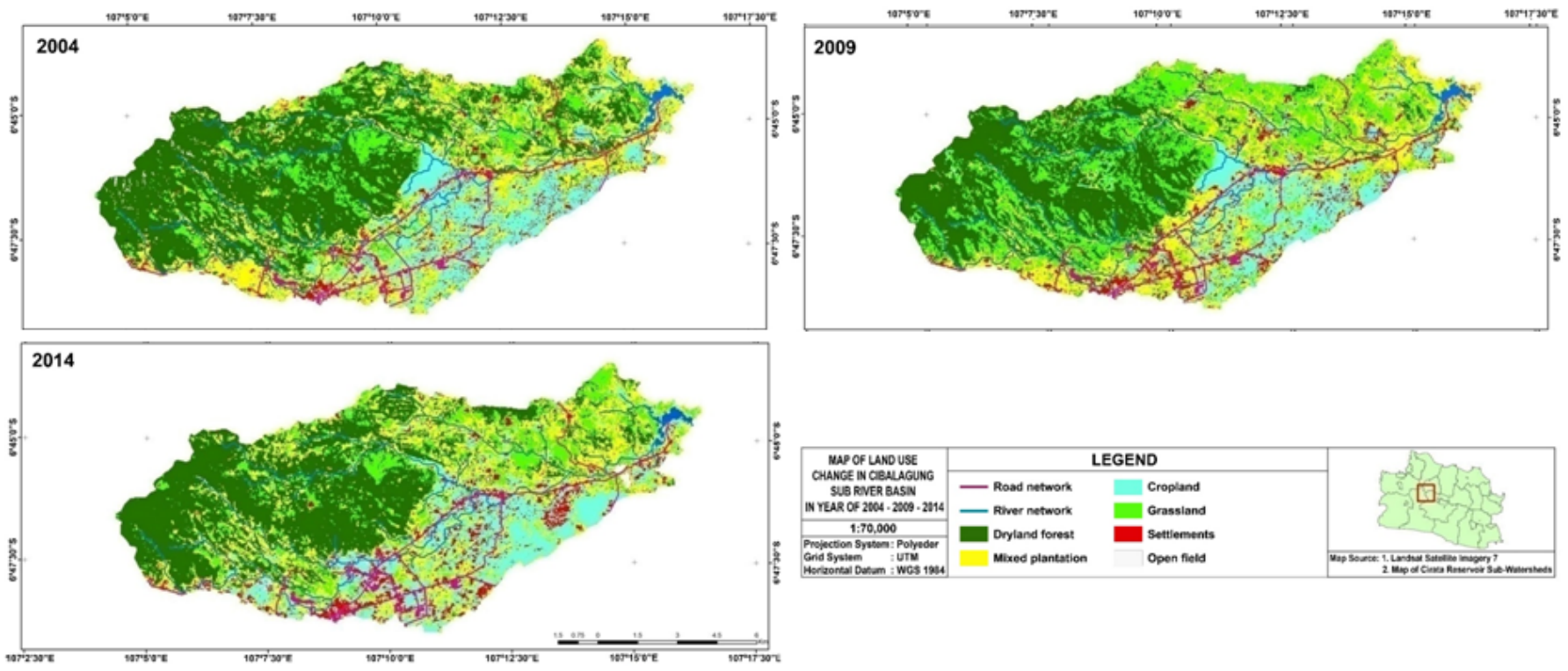

Figure 3. Land-Use Changes in Cibalagung Sub-Watershed.

Table 3. Significance of Test Results of Exogenous Variables

\begin{tabular}{ccc}
\hline Land-use & $\beta$-coefficient & Significance value \\
\hline Dryland forest (DF) & 0.0006 & 0.93 \\
Mixed plantations (MP) & 0.2859 & 0 \\
Cropland (CL) & 0.0788 & 0 \\
Grassland (GL) & -0.0326 & 0 \\
Settlements (SM) & 0.1209 & 0 \\
Open field (OF) & -0.0022 & 0.98 \\
\hline
\end{tabular}

positive effect on TSS content. The presence of vegetation along the riparian zone particularly in the lower catchment zone will eventually protect discharges of the pollutants to the river stream (Zaimes et al., 2011). We also found that TSS content was largely affected by the land-use change from the mixed plantations by $49.50 \%$, i.e. $40.40 \%$ directly and 9.10 $\%$ indirectly. The indirect effect explains that about $9.10 \%$ of changes in TSS value were due to the changes in mixed plantations correlated with changes in other land-use classes. The vegetation coverage in the mixed plantations can reduce erosion rate, as one of the ecosystem services provided by vegetated land. TSS content was also slightly affected by the change of settlements (about $23.7 \%$ ), i.e. $15.4 \%$ directly and $5.9 \%$ indirectly. Settlements area increases the water discharge due to lower absorption ability of land surface caused by asphalt or cement (Widiawaty and Dede, 2018), then eventually increase the sediment runoff when flowing across the bare land (Arsyad, 2009). Therefore, $49.86 \%$ increase in the settlement area, in the period of 2004-2014, had a positive effect on the fluctuation of TSS content by $23.70 \%$.

TSS content was also affected by the increase of cropland by $15.10 \%$, i.e. $10.20 \%$ directly and $4.80 \%$ indirectly. Cropland is believed to have a small erosion rate due to the existence of terraces and rice fields that holds water and soils, soil loss in cropland can increase erosion mainly due to poor land management. Particles from the cropland dilute in the water that flows during soil puddling and weeding, and further, they pollute the surrounding environment. The increase in TSS content in the reservoir was attributed also to the change of grassland by 6.50 $\%$, i.e. $5.0 \%$ directly and $1.50 \%$ indirectly. The increased area 
Table 4. Total Effect Value to The TSS Content

\begin{tabular}{|c|c|c|c|c|c|c|c|c|}
\hline \multirow{2}{*}{ Land-use } & \multirow{2}{*}{ Direct effect (DE) } & \multicolumn{4}{|c|}{ Indirect effect (IE) } & \multirow{2}{*}{ Total (IE) } & \multicolumn{2}{|c|}{$\begin{array}{l}\text { Total effect } \\
(\mathrm{DE}+\mathrm{IE})\end{array}$} \\
\hline & & MP & CL & GL & SM & & Total & $\%$ \\
\hline MP & 0.4 & 0 & 0.03 & 0.01 & 0.04 & 0.09 & 0.49 & 49.58 \\
\hline CL & 0.1 & 0.03 & 0 & 0 & 0.01 & 0.05 & 0.15 & 15.1 \\
\hline GL & 0.05 & 0.01 & 0 & 0 & 0 & 0.01 & 0.06 & 6.5 \\
\hline SM & 0.15 & 0.04 & 0.015 & 0 & 0 & 0.06 & 0.24 & 23.7 \\
\hline Total effect & 0.71 & & & & & 0.21 & 0.92 & 92.5 \\
\hline & $71.20 \%$ & & & & & $21.30 \%$ & & \\
\hline
\end{tabular}

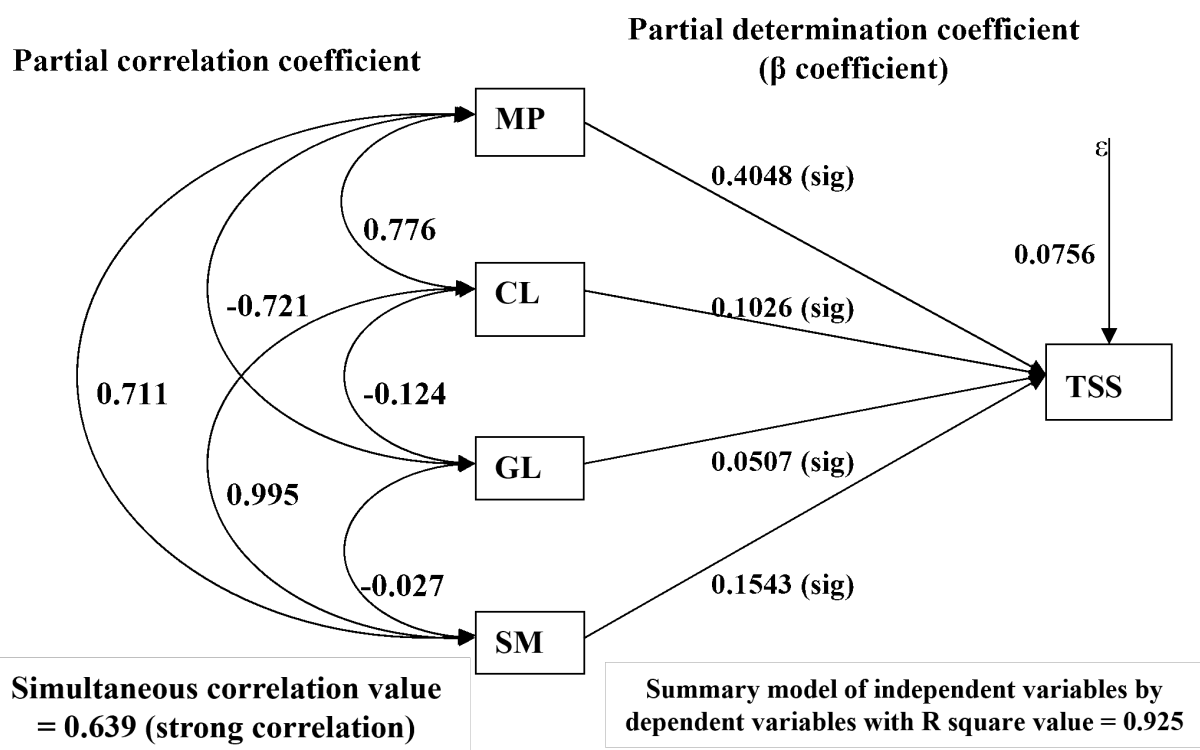

Figure 4. Path Analysis Structural Model of Land-Use on TSS in Cibalagung Sub-Watershed.

of grassland was allegedly due to the clearing activity of the dryland forest that changed to grassland. However then, there was a decrease in grassland which was due to land changes activities for mixed plantations, cropland, and settlements. Grassland area is an area that is dominated by various types of undergrowth, grass, thicket, and reeds that can withstand the surface water flow and soil particles to be discharged to the river. This result was somehow similar to the pattern found in other studies located in the tropical catchment, where the conversion of grass and shrubland for agricultural purposes has increased the volume of sediment yields (Welde and Gebremariam, 2017). The grassland is observed to have a regulatory effect on the erosion rate (Abdulkareem et al., 2019).

Overall, the dynamics of land-use changes that occurred in the Cibalagung sub-watershed had a fairly strong effect on the dynamics of TSS, by $92.50 \%$, i.e. $71.20 \%$ directly and $21.30 \%$ indirectly. Nevertheless, the path coefficient outside the model had an error coefficient ( $\varepsilon$ value) of 0.075 or 7.50 $\%$, indicating that the unidentified variables may remarkably contribute to the dynamics of TSS content. The dryland forest and open field were expected to have a significant influence on the dynamics of TSS in river waters, even though they were excluded from the analysis. Dryland forest as an area with plant cover from various strata can provide great rainwater retain. The vegetation roots are useful as water storage pockets that can reduce the rate of erosion and hold off the surface water flow that brings soil sediment. Meanwhile, open field is the biggest contributor to river water sediments as it makes surface water easily dissolve the sediment, and flow the soil particles into rivers. Such conditions are happening in all parts of river catchment as a result of land conversion activities, especially in mixed plantations (Sutono et al., 2002). However, due to the small size of open land, during the period of study, such an effect is minuscule to be detected.

\section{CONCLUSIONS}

The model presented in this study illustrates the interrelationships of land-use changes in Cibalagung sub-watershed dynamics affecting water quality in the reservoir. Land-use changes in the Cibalagung sub-watershed in the period of 2004-2014 
showed a decrease in dryland forest by 1077.78 ha, and an increase in mixed plantations by 123.03 ha; cropland, by 521.92 ha; grassland, by 57.96 ha; settlements, by 315.81 ha; and open field, by 67.4 ha. Directly and indirectly, an increase of mixed plantations, cropland, settlements, and grassland contributed to the rise of TSS content in the estuary by $49.50 \%$, $15.10 \%, 23.70 \%$, and $6.50 \%$, respectively. Overall, the four land-uses contributed to the TSS content in the Cibalagung River waters by $92.50 \%$, and the other $7.50 \%$ comes from factors outside of the model. This study states that conservation efforts through vegetative methods are more effective in controlling the rate of soil release and increasing TSS in the Cirata Reservoir. The government and stakeholders need to reforest critical lands accompanied by technical efforts such as terracing, installing groins/gabions, and regular monitoring of water quality.

\section{ACKNOWLEDGEMENT}

The authors thank to Center for the Environment and Sustainability Science (CESS), Universitas Padjadjaran for their support in provisioning all the analysis instruments. We also thank to the laboratorium staffs at CESS for their help with the water quality data collection.

\section{REFERENCES}

Abdulkareem, J., B. Pradhan, W. Sulaiman, and N. Jamil (2019). Prediction of Spatial Soil Loss Impacted by LongTerm Land-Use/Land-Cover Change in a Tropical Watershed. Geoscience Frontiers, 10(2); 389-403

Al Fugara, A. M., B. Pradhan, and T. Ahmed Mohamed (2009). Improvement of Land-Use Classification Using Object-Oriented and Fuzzy Logic Approach. Applied Geomatics, 1(4); 111-120

Annandale, G. W. (1987). Reservoir Sedimentation. Elsevier

Arsyad, S. (2009). Konservasi Tanah dan Air. PT Penerbit IPB Press. (in Indonesia)

Ben-David, A. (2008). Comparison of Classification Accuracy Using Cohen's Weighted Kappa. Expert Systems with Applications, 34(2); 825-832

Chen, R. S. and C. M. Tsai (2017). Development of an Evaluation System for Sustaining Reservoir Functions-a Case Study of Shiwen Reservoir in Taiwan. Sustainability, 9(8); 1387

Chen, S., L. Han, X. Chen, D. Li, L. Sun, and Y. Li (2015). Estimating Wide Range Total Suspended Solids Concentrations from MODIS 250-m imageries: An Improved Method. ISPRS Journal of Photogrammetry and Remote Sensing, 99; 5869

Congalton, R. G. (1991). A Review of Assessing The Accuracy of Classifications of Remotely Sensed Data. Remote Sensing of Environment, 37(1); 35-46

Congalton, R. G. and K. Green (2019). Assessing The Accuracy of Remotely Sensed Data: Principles and Practices. CRC Press

Cramer, C., T. Wehner, and S. Donaghy (1999). PATHSAS:
A SAS Computer Program for Path Coefficient Analysis of Quantitative Data. Journal of Heredity, 90; 260-262

Dede, M., C. Asdak, and I. Setiawan (2021). Spatial Dynamics Model of Land Use and Land Cover Changes: A Comparison of CA, ANN, and ANN-CA. Register: Jurnal Ilmiah Teknologi Sistem Informasi, 8(1); 38-49

Dede, M., M. A. Widiawaty, G. P. Pramulatsih, A. Ismail, A. Ati, and H. Murtianto (2019). Integration of Participatory Mapping, Crowdsourcing and Geographic Information System in Flood Disaster Management (Case Study Ciledug Lor, Cirebon). Journal of Information Technology and its Utilization, 2(2); 44-47

El-Askary, H., S. Abd El-Mawla, J. Li, M. El-Hattab, and M. El-Raey (2014). Change Detection of Coral Reef Habitat Using Landsat-5 TM, Landsat 7 ETM+ and Landsat 8 OLI Data in The Red Sea (Hurghada, Egypt). International Journal of Remote Sensing, 35(6); 2327-2346

Erol, A. and T. O. Randhir (2013). Watershed Ecosystem Modeling of Land-Use Impacts on Water Quality. Ecological Modelling, 270; 54-63

Espa, P., M. L. Brignoli, G. Crosa, G. Gentili, and S. Quadroni (2016). Controlled Sediment Flushing at The Cancano Reservoir (Italian Alps): Management of The Operation and Downstream Environmental Impact. Journal of Environmental Management, 182; 1-12

Firdaus, R., N. Nakagoshi, et al. (2013). Assessment of The Relationship Between Land Use Land Cover and Water Quality Status of The Tropical Watershed: A Case of Batang Merao Watershed, Indonesia. Journal of Biodiversity and Environmental Sciences, 3(11); 21-30

George, M. W., R. H. Hotchkiss, and R. Huffaker (2017). Reservoir Sustainability and Sediment Management. Journal of Water Resources Planning and Management, 143(3); 04016077

Giri, C. P. (2012). Remote Sensing of Land Use and Land Cover: Principles and Applications. CRC Press

Gounaridis, D., G. N. Zaimes, and S. Koukoulas (2014). Quantifying Spatio-Temporal Patterns of Forest Fragmentation in Hymettus Mountain, Greece. Computers, Environment and Urban Systems, 46; 35-44

Graf, W. L., E. Wohl, T. Sinha, and J. L. Sabo (2010). Sedimentation and Sustainability of Western American Reservoirs. Water Resources Research, 46(12); W12535

Hassani, M., M. C. Chabou, M. Hamoudi, and M. S. Guettouche (2015). Index of Extraction of Water Surfaces from Landsat 7 ETM+ Smages. Arabian Journal of Geosciences, 8(6); 3381-3389

Ho, M., U. Lall, M. Allaire, N. Devineni, H. H. Kwon, I. Pal, D. Raff, and D. Wegner (2017). The Future Role of Dams in The United States of America. Water Resources Research, 53(2); 982-998

Imen, S., N. B. Chang, and Y. J. Yang (2015). Developing The Remote Sensing-Based Early Warning System for Monitoring TSS Concentrations in Lake Mead. Journal of Environmental Management, 160; 73-89 
Ismail, A., M. Dede, M. A. Widiawaty, et al. (2020). Urbanisasi Dan HIV di Kota Bandung (Perspektif Geografi Kesehatan). Buletin Penelitian Kesehatan, 48(2); 139-146. (in Indonesia)

Jiang, N. and L. Fu (1998). Problems of Reservoir Sedimentation in China. Chinese Geographical Science, 8(2); 117-125

Kartamihardja, E. S. and K. Krismono (2016). Ekologi dan Pengelolaan Perikanan Waduk Kaskade Sungai Citarum. Purwakarta: Amafrad Press. (in Indonesia)

Lepage, H., M. Launay, J. Le Coz, H. Angot, C. Miège, S. Gairoard, O. Radakovitch, and M. Coquery (2020). Impact of Dam Flushing Operations on Sediment Dynamics and Quality in The Upper Rhône River, France. Journal of Environmental Management, 255; 109886

Li, Q., M. Yu, G. Lu, T. Cai, X. Bai, and Z. Xia (2011). Impacts of The Gezhouba and Three Gorges Reservoirs on The Sediment Regime in The Yangtze River, China. Journal of Hydrology, 403(3-4); 224-233

Li, S., S. Gu, W. Liu, H. Han, and Q. Zhang (2008). Water Quality in Relation to Land Use and Land Cover in The Upper Han River Basin, China. Catena, 75(2); 216-222

Mancino, G., A. Ferrara, A. Padula, and A. Nolè (2020). Cross-Comparison Between Landsat 8 (OLI) and Landsat 7 (ETM+) Derived Vegetation Indices in a Mediterranean Environment. Remote Sensing, 12(2); 291

Moelyo, M. T. and H. I. Januar (2012). Forecast Total Distribution and Large Suspended Sediment Basis Point Sediment Particles Catchment of Cirata Reservoir. In In Proceedings of National Seminar on Limnology at Palembang

Mousavi, S. M., S. Roostaei, and H. Rostamzadeh (2019). Estimation of Flood Land Use/Land Cover Mapping by Regional Modelling of Flood Hazard at Sub-Basin Level Case Study: Marand Basin. Geomatics, Natural Hazards and Risk, 10(1); 1155-1175

Muñoz, J. G., F. Montalban, J. Gras, P. G. Rubí, and F. Matador (2006). Environmental Integrated Rules in Dams with Water Quality Problems: The Santomera Dam, an Example on How to Integrate Water Quality and Water Quantity Needs. Dams and Reservoirs, Societies and Environment in The $21^{\text {st }}$ century; 237-244

Nguyen, H. H., N. H. Nghia, H. T. T. Nguyen, A. T. Le, L. T. N. Tran, L. V. K. Duong, S. Bohm, and M. J. Furniss (2020). Classification Methods for Mapping Mangrove Extents and Drivers of Change in Thanh Hoa Province, Vietnam During 2005-2018. Forest and Society, 4(1); 225-242

Nukazawa, K., S. Kajiwara, T. Saito, and Y. Suzuki (2020). Preliminary Assessment of The Impacts of Sediment Sluicing Events on Stream Insects in The Mimi River, Japan. Ecological Engineering, 145; 105726

Parikesit, S. H., E. Triharyanto, B. Gunawan, A. O. Sunardi, and R. Ohtsuka (2005). Multi-Source Water Pollution in The Upper Citarum Watershed, Indonesia, with Special Reference to its Spatiotemporal Variation. Environmental Sciences: an International Journal of Environmental Physiology and Toxicology, 12(3); 121-131

PJB BPWC (2019). Report on Feasibility Study for Ordering and Arrangement of The Floating Net Cage of Cirata Reservoir. Technical report, Bandung, Center for Environment and Sustainability Science, Universitas Padjadjaran

Raje, D. and P. Mujumdar (2010). Reservoir Performance Under Uncertainty in Hydrologic Impacts of Climate Change. Advances in Water Resources, 33(3); 312-326

Razad, A. A., S. Samsudin, A. Setu, N. Abbas, L. M. Sidek, and H. Basri (2020). Investigating The Impact of Land Use Change on Sediment Yield for Hydropower Reservoirs Through GIS Application. In IOP Conference Series: Earth and Environmental Science, 540; 012037

Ridwansyah, I., M. Yulianti, S. I. Onodera, Y. Shimizu, H. Wibowo, and M. Fakhrudin (2020). The Impact of Land Use and Climate Change on Surface Runoff and Groundwater in Cimanuk Watershed, Indonesia. Limnology, 21(3); 487-498

Setiawan, I., M. Dede, D. Sugandi, and M. A. Widiawaty (2019). Investigating Urban Crime Pattern and Accessibility Using Geographic Information System in Bandung City. KnE Social Sciences, 3(21); 535-548

Shi, P., Y. Zhang, Z. Li, P. Li, and G. Xu (2017). Influence of Land Use and Land Cover Patterns on Seasonal Water Quality at Multi-Spatial Scales. Catena, 151; 182-190

Simonovic, S. P. (1992). Reservoir Systems Analysis: Closing Gap Between Theory and Practice. Journal of Water Resources Planning and Management, 118(3); 262-280

Siswanto, S. Y. and F. Francés (2019). How Land Use/Land Cover Changes Can Affect Water, Flooding and Sedimentation in a Tropical Watershed: A Case Study Using Distributed Modeling in The Upper Citarum Watershed, Indonesia. Environmental Earth Sciences, 78(17); 1-15

Sunardi, S., M. Ariyani, M. Agustian, S. Withaningsih, P. Parikesit, H. Juahir, A. Ismail, and O. S. Abdoellah (2020). Water Corrosivity of Polluted Reservoir and Hydropower Sustainability. Scientific Reports, 10(1); 1-8

Sutono, S., S. Tala'ohu, O. Sopandi, and F. Agus (2002). Soil Loss as Affectes by Different Land Uses in Citarum River Basin, West Java. Proceedings of National Seminar on Multifunctionality and Conversion of Agricultural Land Bogor, 113-133

Teas, R. K., J. G. Wacker, and R. E. Hughes (1979). A Path Analysis of Causes and Consequences of Salespeople's Perceptions of Role Clarity. Journal of Marketing Research, 16(3); 355-369

Varol, M. (2020). Spatio-Temporal Changes in Surface Water Quality and Sediment Phosphorus Content of a Large Reservoir in Turkey. Environmental Pollution, 259; 113860 Wahyudiana, Y. (2019). Perubahan Lingkungan Air dan Dampaknya Terhadap Produksi Listrik di PLTA Cirata. Jurnal TEDC, 13(3); 324-332. (in Indonesia)

Wang, Y. G., S. S. Wang, and J. Dunlop (2015). Statistical Modelling and Power Analysis for Detecting Trends in Total Suspended Sediment Loads. Journal of Hydrology, 520; 439447

Welde, K. and B. Gebremariam (2017). Effect of Land Use Land Cover Dynamics on Hydrological Response of Watershed: Case Study of Tekeze Dam Watershed, Northern 
Ethiopia. International Soil and Water Conservation Research, $5(1) ; 1-16$

Widiawaty, M. A. (2019). Mari Mengenal Sains Informasi Geografis. INA-Rxiv. (in Indonesia)

Widiawaty, M. A. and M. Dede (2018). Pemodelan Spasial Bahaya dan Kerentanan Bencana Banjir di Wilayah Timur Kabupaten Cirebon. Jurnal Dialog Penanggulangan Bencana, 9(2); 142-153. (in Indonesia)

Widiawaty, M. A., A. Ismail, M. Dede, and N. Nurhanifah (2020a). Modeling Land Use and Land Cover Dynamic Using Geographic Information System and Markov-CA. Geosfera Indonesia, 5(2); 210-225

Widiawaty, M. A. and H. M. Nandi (2020). Physical and Social Factors of Shoreline Change in Gebang, Cirebon Regency 1915-2019. Geospatial Information, 4(1); 327-334

Widiawaty, M. A., N. Nandi, and H. Murtianto (2021). Dampak Fisik dan Sosial Perubahan Garis Pantai di Kecamatan Gebang, Kabupaten Cirebon. Seminar Nasional Geomatika, 4; 667-678. (in Indonesia)

Widiawaty, M. A., N. Nurhanifah, A. Ismail, and M. Dede (2020b). The Impact of Cirebon Coal-Fired Power Plants on Water Quality in Mundu Bay, Cirebon Regency. Sustinere: Journal of Environment and Sustainability, 4(3); 189-204

Widiyati, A. (2011). Rancang Bangun Model Pengeleloan Waduk Berkelanjutan Berbasis Perikanan Budidaya Karamba Jaring Apung (Kasus Waduk Cirata Jawa Barat). Technical Report, IPB University. (in Indonesia)

Zaimes, G. N., D. Gounaridis, and D. Fotakis (2011). Assessing Riparian Land-Uses/Vegetation Cover Along The Nestos River in Greece. Fresenius Environmental Bulletin, 20(12); $3217-3225$

Zaimes, G. N., D. Gounaridis, and E. Symenonakis (2019). Assessing The Impact of Dams on Riparian and Deltaic Vegetation Using Remotely-Sensed Vegetation Indices and Random Forests Modelling. Ecological Indicators, 103; 630641

Zhang, J., P. Li, and J. Wang (2014). Urban Built-Up Area Extraction from Landsat TM/ETM+ Images Using Spectral Information and Multivariate Texture. Remote Sensing, 6(8); $7339-7359$ 